\title{
sciendo
}

\section{EFFECT OF ELECTRICAL AND MECHANICAL STUNNING ON RABBIT MEAT QUALITY TRAITS*}

\author{
Joanna Składanowska-Baryza ${ }^{1 *}$, Agnieszka Ludwiczak¹, Ewa Pruszyńska-Oszmałek², \\ Paweł Kołodziejski², Przemysław Racewicz ${ }^{3}$, Marek Stanisz ${ }^{1}$
}

'Department of Animal Breeding and Product Quality Assessment,

Faculty of Veterinary Medicine and Animal Science, Poznań University of Life Sciences, Złotniki, Słoneczna 1, 62-002 Suchy Las, Poland

${ }^{2}$ Department of Animal Physiology and Biochemistry, Faculty of Veterinary Medicine and Animal

Science, Poznań University of Life Sciences, 35 Wołyńska Street, 60-637 Poznań, Poland

${ }^{3}$ Department of Animal Breeding and Product Quality Assessment. Division of Veterinary Public

Health Protection, Poznan University of Life Sciences, Złotniki, Słoneczna 1, 62-002 Suchy Las, Poland

•Corresponding author: joanna.skladanowska-baryza@up.poznan.pl

\begin{abstract}
Increased interest in the production of rabbit meat justifies the need to assess and improve the welfare of these animals not only during the production cycle but also at slaughter. Therefore, the aim of this study was to assess the effects of different stunning methods on the level of blood biochemical parameters (stress indicators), and meat quality of slaughter rabbits. Rabbits of the Hycole line $(n=60)$ were subjected to the following stunning methods: mechanical with a non-penetrating captive bolt (group I; $\mathbf{n}=\mathbf{2 0}$ ), mechanical by hitting a narrow rod on the head (group II; $\mathbf{n}=\mathbf{2 0}$ ), and electrical stunning $(n=20)$. In the stunning groups there were no differences found in the blood level of insulin, cortisol, glucose, total cholesterol, triglycerides, non-esterified fatty acids, and protein content $(\mathrm{P}>0.05)$. The stunning method did not affect the $\mathrm{pH}$ of rabbit meat $(\mathrm{P}=\mathbf{0 . 7 6 8})$, but significantly influenced the $L^{*}$ and $b^{*}$ colour parameters. The muscles of longissimus thoracis et lumborum, from the group of rabbits mechanically stunned by hitting a narrow rod on the head, were the darkest $(L *=58.4)$, with the lowest yellowness values $\left(b^{*}=4.04\right)$. The meat of electrically stunned rabbits was characterised by higher drip loss $(\mathrm{P}<0.001)$, lower plasticity $(\mathrm{P}=\mathbf{0 . 0 4 3})$, and higher free water content $(\mathrm{P}=\mathbf{0 . 0 4 3})$. From the analysed texture measures, only the Warner Bratzler Shear Energy values of the cooked meat were affected by the stunning method. These values were higher in the meat of the mechanically stunned groups compared to the electrically stunned rabbits $(\mathrm{P}=\mathbf{0 . 0 4 2})$. The percentage of dry matter, crude protein, extractable fat and water to protein ratio, were affected only by the muscle type $(P<0.001)$. To conclude, the rabbit meat was characterised by good quality, with only slight differences between the groups. No differences were found in the stress reaction of rabbits subjected to the examined stunning methods.
\end{abstract}

Key words: meat, meat quality, rabbit, stunning method, welfare

*The research was supported by the 2020 grant of the Young Researcher Program of the Faculty of Veterinary Medicine and Animal Science Poznan University of Life Sciences, Składanowska-Baryza financed by the Polish Ministry of Science and Higher Education. 
In recent years, there has been a growing interest in rabbit meat production and consumption, with an appreciation of the dietary and health benefits (Kowalska et al., 2012). Today's consumers focus not only on the quantity or nutritional value of food, but also on the way it is obtained. Nowadays, animal production in Western Europe is subject to consumer criticism concerning appropriate levels of animal welfare on the farm during the pre-slaughter and slaughter phases of the production chain (Apata et al., 2012; Cullere and Dalle Zotte, 2018). The product is perceived to reflect the quality of animal welfare. For many consumers, decreased welfare is linked to poor product quality (Broom, 2010). Stunning is an essential slaughtering procedure ensuring insensibility as quickly and painlessly as possible (Joseph et al., 2013). There are various stunning methods, including electrical, mechanical, and gas stunning (Apata et al., 2012; Składanowska-Baryza and Stanisz, 2019). In the European Union, the most popular method of stunning rabbits is electrical stunning, with $49 \mathrm{~V}$ and $250 \mathrm{~Hz}$ the most frequently used. Rabbits receive a 2-second electroshock to the frontal sinus (Fossa temporalis), with a "V" shaped metal electrode (Lopez et al., 2008). Another method is mechanical stunning which entails the use of either a captive bolt, hammer, or a narrow rod. Captive bolt stunning may be penetrative or non-penetrative. This method is based on an immediate and rapid disruption of brain function. The person who performs the mechanical stunning must be adequately trained to be able to monitor the signs of the stunning's effectiveness (Devine et al., 2004). Another method is gas stunning using a properly balanced gas mixture. This mixture is made up of different proportions of oxygen, $\mathrm{CO}_{2}$, nitrogen, and argon, in a single-phase or twophase sequence (Apata et al., 2012). Stunning animals before slaughter is a mandatory procedure in the European Union, USA, United Kingdom, Australia, New Zealand, South Africa, Brazil, and East Asian countries (Aghwan and Regenstein, 2019).

Currently, the main objectives in the production of rabbit fryers (rabbits slaughtered for meat) are the improvement of: fattening traits (daily weight gain, feed conversion ratio), slaughter traits (meatiness, dressing percentage), and meat quality (high utility for chilled storage). The rabbit industry offers a wide variety of synthetic lines characterised by very good production traits. The research hypothesis is that the stunning method used for rabbit slaughter has an impact on rabbit welfare (revealed in the form of a stress reaction), and then on the quality of rabbit meat (due to the fact that stress affects the course of biochemical changes in the muscle post-mortem). The aim of the present study was to assess the effect of three different stunning methods on blood biochemical parameters of stunned rabbits and to also assess the effect on the quality of rabbit meat. The mentioned research goal was undertaken because of the need to improve the welfare of rabbits during the whole production cycle, including slaughter.

\section{Material and methods}

\section{Animals}

The study was conducted on a group of 60 Hycole rabbits. The rabbits were raised in the same rabbitry. They were weaned at the age of 42 days, after which 
they were all fed the same diet. All rabbits in the experiment were slaughtered at the age of 86 days. During the fattening period, the rabbits were fed with granulated commercial feed containing: $16.0 \%$ crude protein, $14.0 \%$ crude fibre and $10.4 \mathrm{MJ}$ of metabolisable energy, with unlimited access to water. Animals were deprived of food $24 \mathrm{~h}$ prior to slaughter but had unlimited access to water. Prior to slaughter, the animals were weighed and divided into three separate groups, according to stunning method: mechanical, using a non-penetrating captive bolt (group I; $\mathrm{n}=20$ ), mechanical, by hitting the head with a narrow rod (group II; $\mathrm{n}=20$ ), and electrical stunning, using a current of $49 \mathrm{~V}$ for $15 \mathrm{sec}(\mathrm{n}=20)$. The stunning was immediately followed by the cutting of the jugular veins (Council Regulation (CE) No 1099/2009; Council of the European Union, 2009). The animals were hung by the hind limbs in order to allow bleeding out. The carcasses were weighed directly after the dressing-out (hot carcass weight, kg). Twenty-four hours post-mortem the carcasses were reweighed (cold carcass weight, $\mathrm{kg}$ ). The hot and cold carcass weight was used to calculate the hot and cold dressing percentage. The right and left musculus longissimus thoracis et lumborum (LTL) and musculus biceps femoris (BF) of the carcasses were cut out in order to examine the rabbit meat quality. During the analysis, the muscles were kept at $+2^{\circ} \mathrm{C}$. The dressing percentage was calculated as a relation of the cold carcass weight to the pre-slaughter body weight.

\section{Blood stress biomarkers}

The level of rabbit response to stress caused by different stunning methods was evaluated using the baseline serum levels of cortisol, insulin, glucose, total cholesterol, triglycerides, non-esterified fatty acids (NEFA), and protein. After slaughter, the blood from each hanging animal's jugular vein was drained into a plastic testtube. The blood samples were left to clot for $30 \mathrm{~min}$ and were then centrifuged at $3500 \mathrm{~g}$ for $15 \mathrm{~min}$ at $4^{\circ} \mathrm{C}$, then the separated serum was transferred to new tubes and stored at $-20^{\circ} \mathrm{C}$ for further processing. The metabolic profile was defined using commercially available enzymatic colorimetric diagnostic tests according to the manufacturer's instructions. Triglycerides (cat. no. T7531), total cholesterol (cat. no. C7509), glucose (cat. no. G7519), and crude protein (cat. no. T7528) levels were determined using Pointe Scientific reagent kits (Pointe Scientific Polska Sp. z o.o., Warsaw, Poland). The concentration of NEFA was measured using a NEFA determination kit (HR Series NEFA-HR2, Wako Diagnostics, Richmond, VA, USA). The optical density of the samples was determined using a Synergy 2 (BioTek, Winooski, VT, USA) microplate reader. The serum hormonal profile was determined using radioimmunoassay (RIA) kits. All procedures were performed following the manufacturer's instructions. Cortisol was assayed using the CortisolRIA kit (cat. no. IM1841, Beckman Coulter, Prague, Czech Republic). Insulin was determined using the Insulin RIA kit (cat. No. HI-14K. Merck Millipore, Burlington, VT, USA). The radioactivity of the samples was measured by a Wallac Wizard 1470 Gamma Counter (Perkin Elmer, Waltham, MA, USA). 


\section{Meat quality parameters}

pH and colour measurements

A calibrated combination glass calomel electrode Lo 406-M6-DXK-S7/25) connected to a portable pH-meter (Mettler Toledo, type 1140) was inserted into LTL and $\mathrm{BF}$ muscles to measure the $\mathrm{pH} 45 \mathrm{~min}\left(\mathrm{pH}_{45 \min }\right), 24 \mathrm{~h}\left(\mathrm{pH}_{24 \mathrm{~h}}\right)$, and $48 \mathrm{~h}\left(\mathrm{pH}_{48 \mathrm{~h}}\right)$ post-mortem. The first colour measures were recorded 45 min post-mortem on the muscle surface. The colour was measured using a portable spectrophotometer CM 700d (Konica Minolta, Amsterdam, Netherlands and lluminant D65, $10^{\circ}$ observer with an $8 \mathrm{~mm}$ diameter aperture size). The CIE system was used to measure the lightness $\left(\mathrm{L}^{*}\right)$, redness $\left(\mathrm{a}^{*}\right)$, and yellowness $\left(\mathrm{b}^{*}\right)(\mathrm{CIE}, 1978)$. The colour measurements were repeated 24 and $48 \mathrm{~h}$ post-mortem, after storage of the muscle samples at $+2{ }^{\circ} \mathrm{C}$.

Water holding capacity and water fractions

The total water, free water, percentage of free water in total water, and plasticity were measured in LTL and BF. The drip loss and cooking loss were measured only in the LTL. All the aforementioned measures were done $24 \mathrm{~h}$ post-mortem.

The drip loss (\%) was measured according to the method of Honikel (1998). Three $\mathrm{cm}$ thick, transverse slices of the analysed muscles $(25-30 \mathrm{~g})$ were weighed, hung on hooks, and placed in a container to reduce evaporation $\left(+2{ }^{\circ} \mathrm{C}\right)$. The samples were reweighed $24 \mathrm{~h}$ later to calculate the change in the weight.

The free water (\%) was measured using the filter paper press method of Grau and Hamm (1953) with modifications of Pohja and Niinivaara (1957). Samples $(0.280-0.320 \mathrm{~g})$ of ground meat were placed on a filter paper between two glass tiles. A force of $2 \mathrm{~kg}$ was applied on each sample for $5 \mathrm{~min}$. The samples were then removed from the filter paper and immediately reweighed to calculate the change in the weight. The calculations were made using the following formula:

Free water $(\%)=($ sample of ground meat - sample of meat after 5 min of $2 \mathrm{~kg}$ pressure) $\times 100 /$ sample of ground meat

Meat plasticity $\left(\mathrm{cm}^{2}\right)$ was expressed as the area of the compressed meat sample used for the measurement of free water, according to the method of Grau and Hamm (1953). The calculations were made using the following formula:

Meat plasticity $\left(\mathrm{cm}^{2}\right)=\left(\right.$ area $\left(\mathrm{cm}^{2}\right)$ sample of meat after 5 min of $2 \mathrm{~kg}$ pressurel meat sample $(\mathrm{g}) \times 0.300$

The cooking loss (\%) was measured according to the method of Honikel (1998). The $3 \mathrm{~cm}$ thick, transverse slices of the analysed muscles $(25-30 \mathrm{~g})$ were firmly packed into thin polyethylene bags which were then placed in a water bath at $90^{\circ} \mathrm{C}$ (for about $30 \mathrm{~min}$ ) until reaching the core temperature of $75^{\circ} \mathrm{C}$ (measured with the thermocouples). Finally, the samples were cooled to room temperature and reweighed after removing the excess moisture with a paper towel. The change in the weight of the sample was calculated (\%).

\section{Texture analyses}

The texture assessment included the measurement of forces and energy used to cut through the sample, and the forces used to bite through the sample. The cutting forces and cutting energy measures were made by the Warner-Bratzler V-shaped blade attached to the TA.XT Plus Texture Analyser (Stable 136 Micro Systems, UK; test speed $2 \mathrm{~mm} / \mathrm{s}$; distance $20 \mathrm{~mm}$; force $20 \mathrm{~g}$ ). Prior to analysis, the muscle samples 
were placed at room temperature. Then, 4 cores $(1.6 \mathrm{~cm}$ diameter $)$ parallel to the muscle fibers were removed from each sample by using a hand-held coring device (cork borer). The Warner-Bratzler measurements included: the force used at the onset of cutting (WB-O; N), the peak force (WB-P; N), and the area under the curve referred to as the shear energy (WB-E; N/mm). The measurement of biting was done on the cooked samples with Volodkevich Bite Jaws (test speed $2 \mathrm{~mm} / \mathrm{s}$; strain 100\%; force $5 \mathrm{~g}$ ). The measurement was done $48 \mathrm{~h}$ post-mortem. The meat samples were obtained from the muscle parts used for the measurement of cooking loss, and these samples were subjected to chilled storage for $24 \mathrm{~h}$ at $2^{\circ} \mathrm{C}$ in plastic bags. Prior to analysis, the muscle parts were placed at room temperature. The Twin Blade Sample Preparation Tool was used to cut $10 \mathrm{~mm} \times 10 \mathrm{~mm}$ size stripes laterally to the muscle fibers (4 stripes per muscle). The following 2 measurements were taken: the initial biting force $(\mathrm{V}-\mathrm{O} ; \mathrm{N})$ and the peak force $(\mathrm{V}-\mathrm{P} ; \mathrm{N})$.

Chemical composition

An analysis of the chemical composition (AOAC, 2007) was made 24 h postmortem and included: the determination of dry matter content (the samples were dried at $105^{\circ} \mathrm{C}$ to a consistent weight), the determination of the crude protein content with the Kjeldahl procedure (K-424 Buchi digestion unit; BüchiLabortechnik AG, Flawil, Switzerland; Schott TitroLine, SCHOTT, Mainz, Germany), and the determination of extractable fat content by Soxhlet extraction with diethyl ether (MLL 147, AJL Electronics, Poland). The determination of dry matter content allowed for the calculation of the percent of total water.

\section{Statistical analyses}

The effect of the stunning method on the hot carcass dressing percentage, cold carcass dressing percentage, hot and cold carcass weight, cortisol, glucose, cholesterol, triglycerides, NEFA, protein, drip loss, cooking loss, WB-O, WB-P, WB-E, $\mathrm{V}-\mathrm{O}$, and $\mathrm{V}-\mathrm{P}$ were calculated with the model given below:

$$
Y_{i j}=\mu+\alpha_{i}+e_{i j}
$$

where:

$\mu$ - the overall mean of the analysed trait,

$\alpha_{i}$ - the fixed effect of the $\mathrm{i}^{\text {th }}$ stunning method $(\mathrm{i}=1,2,3)$,

$e_{i j}-$ the random error.

The effect of the stunning method, muscle type, and time post-mortem on the $\mathrm{pH}$ $\left(\mathrm{pH}_{45 \min }, \mathrm{pH}_{24 \mathrm{~h}}\right.$ and $\left.\mathrm{pH}_{48 \mathrm{~h}}\right)$ and muscle colour: $\mathrm{L}^{*}\left(\mathrm{~L}^{*}{ }_{45 \min }, \mathrm{L}^{*}{ }_{24 \mathrm{~h}}\right.$ and $\left.\mathrm{L}^{*}{ }_{48 \mathrm{~h}}\right), \mathrm{a}^{*}\left(\mathrm{a}^{*}{ }_{45 \min }\right.$, $\mathrm{a}^{*}{ }_{24 \mathrm{~h}}$ and $\left.\mathrm{a}^{*}{ }_{48 \mathrm{~h}}\right)$, and $\mathrm{b}^{*}\left(\mathrm{~b}^{*}{ }_{45 \min }, \mathrm{b}^{*}{ }_{24 \mathrm{~h}}\right.$ and $\left.\mathrm{b}^{*}{ }_{48 \mathrm{~h}}\right)$, was calculated with the model given below:

$$
\mathrm{Y}_{\mathrm{iklm}}=\mu+\alpha_{\mathrm{i}}+\pi_{\mathrm{k}}+\gamma_{\mathrm{k}(1)}+\beta_{\mathrm{k}(\mathrm{l})(\mathrm{m})}+\mathrm{e}_{\mathrm{iklm}}
$$

where:

$\mu$ - the overall mean of the analysed trait, 
$\alpha_{i}$ - the fixed effect of the $\mathrm{i}^{\text {th }}$ stunning method $(\mathrm{i}=1,2,3)$,

$\pi_{k}$ - the random effect of the $\mathrm{k}^{\text {th }}$ animal $(\mathrm{k}=1,2,3, \ldots 60)$,

$\gamma_{k(l)}$ - the random effects of the $1^{\text {th }}$ muscle $(1=1,2)$ nested in the $\mathrm{k}^{\text {th }}$ animal,

$\beta_{k(l)(m)}$ - the effect of the $\mathrm{m}^{\text {th }}$ time post-mortem $(\mathrm{m}=1,2,3)$ as the repeated measures nested in the $1^{\text {th }}$ muscle nested in the $\mathrm{k}^{\text {th }}$ animal,

$e_{i k l m}-$ the random error connected with $\mathrm{iklm}^{\text {th }}$ observation.

The effect of the stunning method and muscle type on the total water, free water, plasticity, dry matter, crude protein, extractable fat, and water/crude protein ratio was calculated with the model given below:

$$
y_{i k l}=\mu+\alpha_{i}+\pi_{k}+\gamma_{k(l)}+e_{i k l}
$$

where:

$\mu$ - the overall mean of the analysed trait,

$\alpha_{i}$ - the fixed effect of the $i^{\text {th }}$ stunning method $(i=1,2,3)$,

$\pi_{k}$ - the random effect of the $\mathrm{k}^{\text {th }}$ animal $(\mathrm{k}=1,2,3, \ldots 60)$,

$\gamma_{k(l)}$ - the random effects of the $1^{\text {th }}$ muscle nested in the $\mathrm{k}^{\text {th }}$ animal,

$e_{i k l}$ - the random error connected with the $\mathrm{ikl}^{\text {th }}$ observation.

There was no interaction between the analysed effects, therefore they were not included in the model. All the statistical analyses were made with SAS (2012). Tukey-Kramer adjustment was implemented for multiple comparisons of LS-mean differences.

\section{Results}

Slaughter traits of rabbits randomly selected to three groups are presented in Table 1 . The analysed groups did not differ in terms of slaughter traits $(\mathrm{P}>0.05)$. Table 2 presents the blood levels of the analysed stress biomarkers of rabbits. The type of stunning method did not affect the concentration of insulin, cortisol, glucose, total cholesterol, triglycerides, NEFA, and crude protein content $(\mathrm{P}>0.05)$. The $\mathrm{pH}$ of two analysed muscles (LTL and BF) was measured $45 \mathrm{~min}, 24 \mathrm{~h}$, and $48 \mathrm{~h}$ after slaughter (Table 3 ). In the present study, the $\mathrm{pH}$ of rabbit meat was not influenced by the stunning method $(\mathrm{P}=0.768)$. The general effect of muscle type on the $\mathrm{pH}$ values found in our study, was not significant (Table 4; $\mathrm{P}=0.214$ ), though the $\mathrm{pH}$ measured $45 \mathrm{~min}$ post-mortem was significantly higher in the LTL compared to BF muscles (Table 3; $\mathrm{P}<0.01)$. The greatest differences were found between $\mathrm{pH}_{45}$ and $\mathrm{pH}_{24}(\mathrm{P}<0.01)$. The $\mathrm{pH}$ of rabbit meat stabilised $24 \mathrm{~h}$ after slaughter, therefore, there was no difference between $\mathrm{pH}_{24}$ and $\mathrm{pH}_{48}(\mathrm{P}>0.05)$. Among the analysed colour parameters the $\mathrm{L}^{*}$ $(\mathrm{P}=0.035)$ and $\mathrm{b}^{*}(\mathrm{P}=0.038)$ values were the most affected by the stunning method (Table 4). The lowest meat brightness was noted 45 min post-mortem in the LTL muscle in the group of rabbits mechanically stunned: with a non-penetrating cap- 
tive bolt and by hitting a narrow rod on the head. After $48 \mathrm{~h}$ post-mortem, the LTL muscles from the group of rabbits mechanically stunned with non-penetrating captive bolt, were still the darkest. Both muscles from all the analysed rabbit groups got significantly brighter with time post-mortem $(\mathrm{P}=0.001)$. The $\mathrm{L}^{*}$ value did not stabilise $24 \mathrm{~h}$ after slaughter, like the $\mathrm{pH}$ value. A significant increase of this parameter could be still observed $24 \mathrm{~h}$ and $48 \mathrm{~h}$ post-mortem. The meat of the group of rabbits mechanically stunned with non-penetrating captive bolt, was characterised by redder LTL muscle, according to the measures taken 45 min post-mortem, and a significant drop of $\mathrm{a}^{*}$ value between $45 \mathrm{~min}$ and $24 \mathrm{~h}$ post-mortem $(\mathrm{P}<0.05)$. The general effects of the stunning methods, time post-mortem, and muscle type on the $a^{*}$ value were not significant (Table 5 ). The $b^{*}$ colour parameter was affected by all the analysed factors: the stunning methods $(\mathrm{P}=0.038)$, time post-mortem $(\mathrm{P}=0.045)$, and the muscle type $(\mathrm{P}=0.028)$ (Table 5$)$. In both muscles of all the stunning groups, the yellowness gradually decreased $45 \mathrm{~min}$ to $48 \mathrm{~h}$ post-mortem (Table 4). After $48 \mathrm{~h}$ post-mortem, the lowest $\mathrm{b}^{*}$ values were found in the LTL muscles of the group of rabbits mechanically stunned by hitting a narrow rod on the head, and the LTL muscle of the electrically stunned group. The most significant decrease of yellowness was noted in the LTL muscle of the group of rabbits electrically stunned by hitting a narrow rod on the head, between 45 min and $48 \mathrm{~h}$ post-mortem $(\mathrm{P}<0.05)$.

Table 1. Effect of the stunning method on carcass slaughter traits of rabbits $(n=60)$

\begin{tabular}{l|c|c|c|c|c|c}
\hline \multicolumn{1}{c|}{ Item } & Mean & $\begin{array}{c}\text { Mechanical } \\
\text { stunning I }\end{array}$ & $\begin{array}{c}\text { Mechanical } \\
\text { stunning II }\end{array}$ & $\begin{array}{c}\text { Electrical } \\
\text { stunning }\end{array}$ & SEM & $\begin{array}{c}\text { Effect } \\
\text { (P-value) }\end{array}$ \\
\hline Body weight at slaughter (g) & 2778 & 2707 & 2849 & 2777 & 62 & 0.273 \\
Hot carcass dressing percentage (\%) & 49.61 & 49.24 & 49.71 & 49.86 & 0.58 & 0.734 \\
Cold carcass dressing percentage (\%) & 47.33 & 46.74 & 47.62 & 47.64 & 0.56 & 0.422 \\
Hot carcass weight (g) & 1381 & 1335 & 1418 & 1386 & 38 & 0.315 \\
Cold carcass weight (g) & 1317 & 1268 & 1358 & 1324 & 36 & 0.214 \\
\hline
\end{tabular}

SEM: standard error of the mean.

Table 2. Effect of the stunning method on the blood levels of stress biomarkers in rabbits $(n=60)$

\begin{tabular}{l|c|c|c|c|c}
\hline \multicolumn{1}{c|}{ Item } & $\begin{array}{c}\text { Mechanical } \\
\text { stunning I }\end{array}$ & $\begin{array}{c}\text { Mechanical } \\
\text { stunning II }\end{array}$ & $\begin{array}{c}\text { Electrical } \\
\text { stunning }\end{array}$ & SEM & $\begin{array}{c}\text { Stunning } \\
\text { method }\end{array}$ \\
\hline Insulin $(\mu \mathrm{U} / \mathrm{ml})$ & 17.31 & 21.41 & 24.19 & 2.97 & 0.475 \\
Cortisol $(\mathrm{nmol} / \mathrm{l})$ & 19.18 & 19.76 & 18.32 & 1.57 & 0.812 \\
Glucose $(\mathrm{mg} / \mathrm{dl})$ & 128.1 & 134.5 & 131.2 & 4.9 & 0.212 \\
Cholesterol $(\mathrm{mg} / \mathrm{dl})$ & 86.5 & 89.3 & 83.8 & 2.8 & 0.394 \\
Triglycerides $(\mathrm{mg} / \mathrm{dl})$ & 78.4 & 79.5 & 79.4 & 1.42 & 0.941 \\
NEFA $(\mathrm{mmol} / \mathrm{l})$ & 0.48 & 0.46 & 0.49 & 0.03 & 0.793 \\
Protein $(\mathrm{g} / \mathrm{dl})$ & 6.71 & 6.89 & 6.75 & 0.12 & 0.896 \\
\hline
\end{tabular}

SEM: standard error of the mean. 


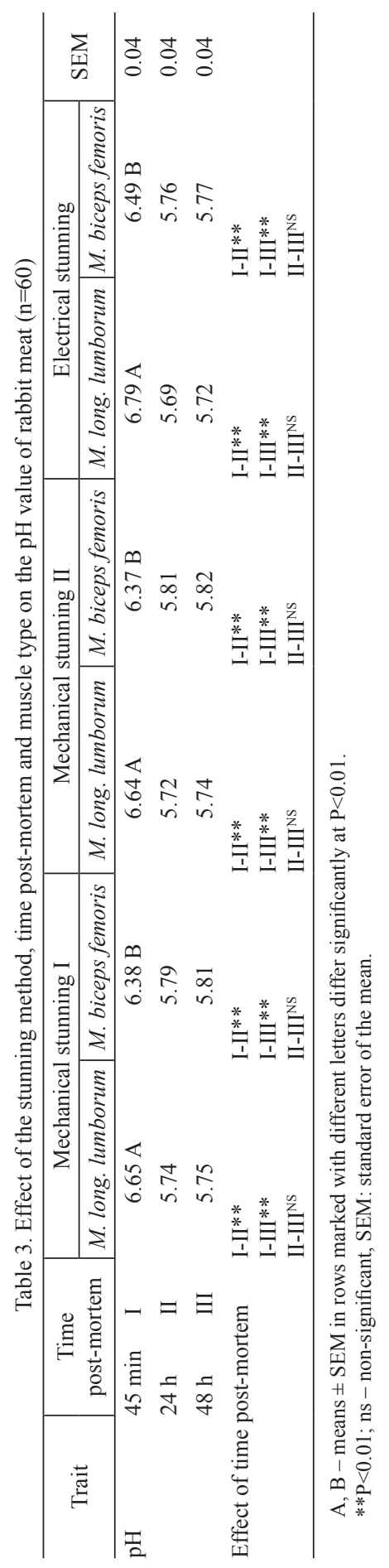




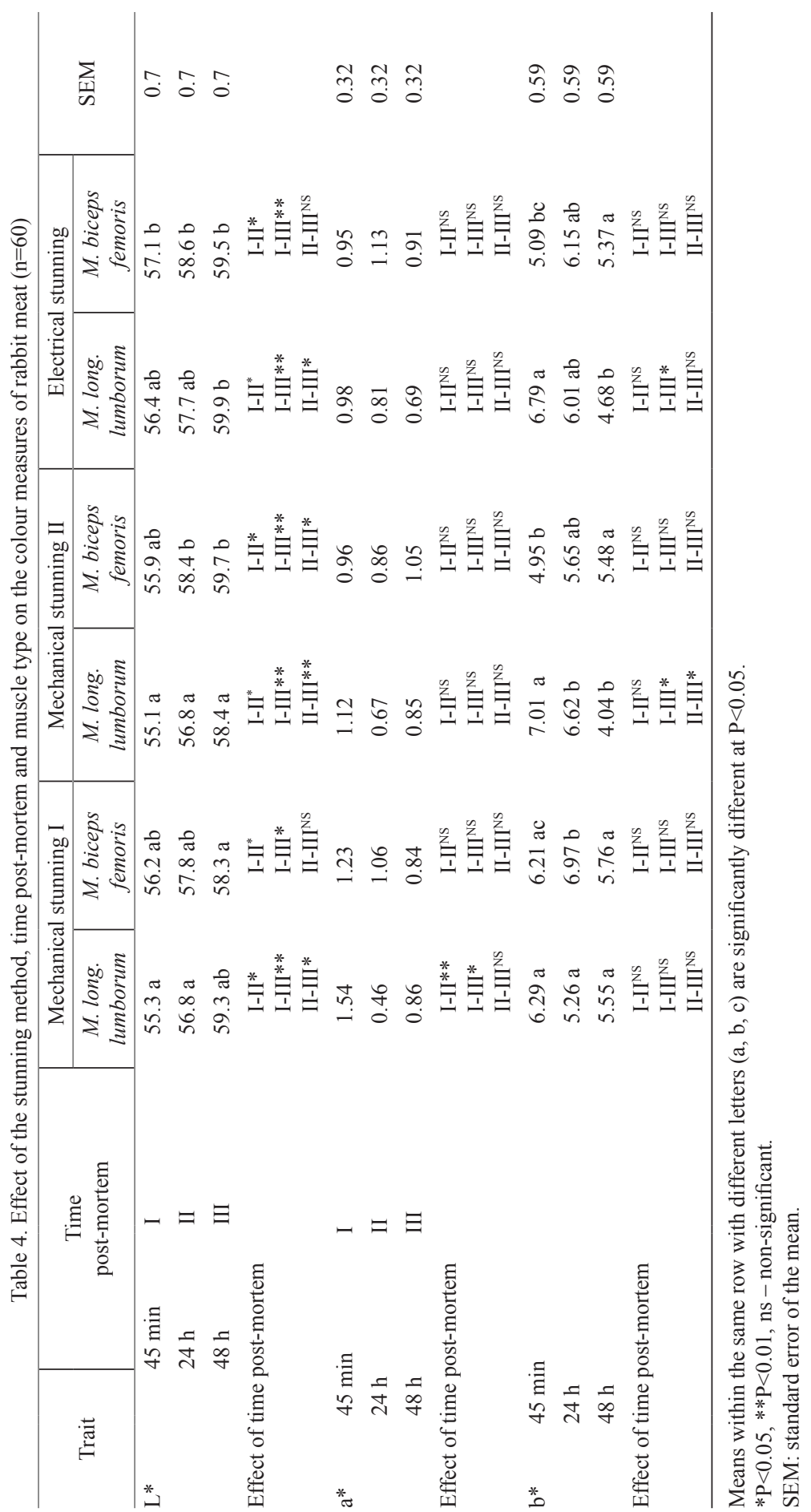


Table 5. Effect of the stunning method, time post-mortem and muscle type on the $\mathrm{pH}$ value and colour of rabbit meat $(n=60)$

\begin{tabular}{l|c|c|c}
\hline \multirow{2}{*}{ Trait } & \multicolumn{3}{|c}{ Effect (P-value) } \\
\cline { 2 - 4 } & Stunning method & Time post-mortem & Muscle type \\
\hline $\mathrm{pH}$ & 0.768 & 0.001 & 0.214 \\
L* value & 0.035 & 0.002 & 0.504 \\
a* value & 0.628 & 0.459 & 0.632 \\
b* value & 0.038 & 0.045 & 0.028 \\
\hline
\end{tabular}

Table 6. Effect of stunning method and muscle type on the water fractions and water holding capacity of the rabbit meat

\begin{tabular}{|c|c|c|c|c|c|c|c|c|c|}
\hline \multirow[b]{2}{*}{ Trait } & \multicolumn{2}{|c|}{ Mechanical stunning I } & \multicolumn{2}{|c|}{ Mechanical stunning II } & \multicolumn{2}{|c|}{ Electrical stunning } & \multirow[b]{2}{*}{ SEM } & \multicolumn{2}{|c|}{ Effect (P-value) } \\
\hline & $\begin{array}{c}\text { M. long. } \\
\text { lumborum }\end{array}$ & $\begin{array}{c}\text { M. biceps } \\
\text { femoris }\end{array}$ & $\begin{array}{l}\text { M. long. } \\
\text { lumborum }\end{array}$ & $\begin{array}{c}\text { M. biceps } f \\
\text { emoris }\end{array}$ & $\begin{array}{l}\text { M. long. } \\
\text { lumborum }\end{array}$ & $\begin{array}{l}\text { M. biceps } \\
\text { femoris }\end{array}$ & & $\begin{array}{l}\text { Stunning } \\
\text { method }\end{array}$ & $\begin{array}{c}\text { Muscle } \\
\text { type }\end{array}$ \\
\hline $\begin{array}{l}\text { Drip loss } \\
(\%)\end{array}$ & $1.66 \mathrm{Aa}$ & - & $1.43 \mathrm{Ab}$ & - & $2.23 \mathrm{~B}$ & - & 0.08 & 0.001 & - \\
\hline $\begin{array}{l}\text { Total } \\
\text { water }(\%)\end{array}$ & 75.9 & 76.4 & 75.9 & 76.4 & 75.9 & 76.4 & 0.2 & 0.968 & 0.121 \\
\hline $\begin{array}{l}\text { Free } \\
\text { water (\%) }\end{array}$ & $28.9 \mathrm{a}$ & $29.9 \mathrm{ab}$ & $29.2 \mathrm{a}$ & $30.1 \mathrm{ab}$ & $32.1 \mathrm{~b}$ & $32.7 \mathrm{~b}$ & 0.7 & 0.043 & 0.018 \\
\hline $\begin{array}{l}\text { Cooking } \\
\text { loss }(\%)\end{array}$ & 23.9 & - & 24.5 & - & 22.6 & - & 0.9 & 0.273 & - \\
\hline $\begin{array}{l}\text { Plasticity } \\
\left(\mathrm{cm}^{2}\right)\end{array}$ & $4.15 \mathrm{a}$ & $4.39 \mathrm{a}$ & $4.05 \mathrm{ac}$ & $4.12 \mathrm{ac}$ & $3.59 \mathrm{~b}$ & $3.76 \mathrm{bc}$ & 0.21 & 0.038 & 0.046 \\
\hline
\end{tabular}

Means within the same row with different letters (A, B) are significantly different at $\mathrm{P}<0.01$.

Means within the same row with different letters (a, b, c) are significantly different at $\mathrm{P}<0.05$.

SEM: standard error of the mean.

Table 7. Effect of the stunning method on the texture measurements of rabbit meat $(n=60)$

\begin{tabular}{|c|c|c|c|c|c|c|c|c|}
\hline \multirow{2}{*}{ Trait } & \multicolumn{2}{|c|}{ Mechanical stunning I } & \multicolumn{2}{|c|}{ Mechanical stunning II } & \multicolumn{2}{|c|}{ Electrical stunning } & \multirow{2}{*}{ SEM } & \multirow{2}{*}{$\begin{array}{c}\text { Effect } \\
\text { (P-value) }\end{array}$} \\
\hline & Raw & Cooked & Raw & Cooked & Raw & Cooked & & \\
\hline \multirow[t]{2}{*}{ WB-O (N) } & 7.2 & - & 7.5 & - & 7.9 & - & 0.7 & 0.626 \\
\hline & - & 12.8 & - & 13.1 & & 15.2 & 1.1 & 0.426 \\
\hline \multirow[t]{2}{*}{ WB-P (N) } & 8.7 & - & 8.9 & - & 9.1 & - & 0.9 & 0.523 \\
\hline & - & 14.1 & - & 13.9 & - & 15.6 & 1.2 & 0.614 \\
\hline \multirow[t]{2}{*}{ WB-E $\left(\mathrm{N}^{*} \mathrm{~mm}\right)$} & 3352 & - & 3312 & - & 3025 & - & 189 & 0.242 \\
\hline & - & $5428 \mathrm{a}$ & - & $5552 \mathrm{a}$ & - & $4663 \mathrm{~b}$ & 359 & 0.042 \\
\hline $\mathrm{V}-\mathrm{O}(\mathrm{N})$ & - & 18.7 & - & 18.4 & - & 21.4 & 1.3 & 0.218 \\
\hline V-P (N) & - & 18.8 & - & 18.5 & - & 21.4 & 1.3 & 0.219 \\
\hline
\end{tabular}

WB-O - Warner Bratzler force at the onset of cutting; WB-P - Warner Bratzler peak force.

WB-P - Warner Bratzler shear energy; V-O - the force at the onset of biting; V-P - the biting peak force.

Means within the same row with different letters $(a, b)$ are significantly different at $\mathrm{P}<0.05$.

SEM: standard error of the mean. 
Table 8. Effect of stunning method and muscle type on the chemical composition of rabbit meat $(n=60)$

\begin{tabular}{|c|c|c|c|c|c|c|c|c|c|}
\hline \multirow[b]{2}{*}{ Trait } & \multicolumn{2}{|c|}{ Mechanical stunning I } & \multicolumn{2}{|c|}{ Mechanical stunning II } & \multicolumn{2}{|c|}{ Electrical stunning } & \multirow[b]{2}{*}{ SEM } & \multicolumn{2}{|c|}{ Effect (P-value) } \\
\hline & $\begin{array}{c}\text { M. long. } \\
\text { lumborum }\end{array}$ & $\begin{array}{l}\text { M. biceps } \\
\text { femoris }\end{array}$ & $\begin{array}{l}\text { M. long. } \\
\text { lumborum }\end{array}$ & $\begin{array}{c}\text { M. biceps } \\
\text { femoris }\end{array}$ & \begin{tabular}{|c|} 
M. long. \\
lumborum
\end{tabular} & $\begin{array}{c}\text { M. biceps } \\
\text { femoris }\end{array}$ & & $\begin{array}{l}\text { Stunning } \\
\text { method }\end{array}$ & $\begin{array}{c}\text { Muscle } \\
\text { type }\end{array}$ \\
\hline $\mathrm{DM}(\%)$ & 24.10 & 23.59 & 24.09 & 23.58 & 24.10 & 23.60 & 0.16 & 0.876 & 0.001 \\
\hline CP $(\%)$ & $22.32 \mathrm{a}$ & $21.43 \mathrm{~b}$ & $22.34 \mathrm{a}$ & $21.52 \mathrm{~b}$ & $22.29 \mathrm{a}$ & $21.43 \mathrm{~b}$ & 0.12 & 0.943 & 0.001 \\
\hline $\mathrm{EF}(\%)$ & $0.69 \mathrm{~A}$ & $1.02 \mathrm{~B}$ & $0.74 \mathrm{~A}$ & $1.05 \mathrm{~B}$ & $0.76 \mathrm{~A}$ & $1.10 \mathrm{~B}$ & 0.11 & 0.989 & 0.001 \\
\hline $\mathrm{W} / \mathrm{CP}$ & 3.40 & 3.56 & 3.40 & 3.54 & 3.41 & 3.56 & 0.06 & 0.953 & 0.001 \\
\hline
\end{tabular}

$\mathrm{DM}$ - dry matter, $\mathrm{CP}$ - crude protein, $\mathrm{EF}$ - extractable fat, $\mathrm{W} / \mathrm{CP}$ - water/crude protein ratio. Means within the same row with different letters $(\mathrm{A}, \mathrm{B})$ are significantly different at $\mathrm{P}<0.01$. Means within the same row with different letters $(a, b)$ are significantly different at $\mathrm{P}<0.05$.

SEM: standard error of the mean.

The meat of the electrically stunned rabbits was characterised by higher drip loss $(\mathrm{P}<0.001)$, lower plasticity $(\mathrm{P}=0.043)$, and higher free water content $(\mathrm{P}=0.043)$ compared to the meat from the mechanically stunned animals (Table 6). Furthermore, the group of rabbits mechanically stunned with non-penetrating captive bolt had a higher $(1.66 \%)$ drip loss compared to group II $(1.43 \%)$. The percentage of free water and the plasticity differed according to the muscle type, and were higher in $\mathrm{BF}$ muscles compared to LTL muscles $(\mathrm{P}=0.018$ and $\mathrm{P}=0.046)$. The total water loss and cooking loss were similar for all the analysed stunning groups.

From the analysed texture methods only, the WB-E values of the cooked meat were affected by the stunning method, and were higher in the meat of mechanically stunned groups compared to the electrically stunned rabbits $(\mathrm{P}=0.042)$ (Table 7).

The chemical composition of rabbit meat is presented in Table 8. As expected, the major factor determining the chemical composition of rabbit meat was the muscle type. The dry matter and crude protein content was higher in LTL compared to $\mathrm{BF}(\mathrm{P}<0.001)$. The percentage of extractable fat and water/crude protein ratio was higher in $\mathrm{BF}$ compared to LTL $(\mathrm{P}<0.001)$. No differences in the chemical composition $(\mathrm{P}>0.05)$ were found between different stunning methods (Table 8$)$.

\section{Discussion}

It is hard to compare the meat performance results from different studies because each farm is a unique environment, even if the farms differ only in some details. Moreover, the slaughter traits are also dependent upon the genotypes of rabbits (Metzger et al., 2006; Paci et al., 2012; Szendro et al., 2010; Tumova et al., 2014. Farm animals are exposed to physical, psychological, and physiological stressors throughout the production cycle (Fazio et al., 2015), but the pre-slaughter period seems to be the most essential from the perspective of meat quality (SkładanowskaBaryza et al., 2018). In their study, Nakyinsige et al. (2014) assessed the effect of gas stunning (GS) and halal slaughter (HS) on rabbit welfare and meat quality. They found the level of blood glucose to be significantly higher in the GS group compared 
to the HS group $(\mathrm{P}<0.05)$. According to Becerril-Herrera et al. (2009), the use of $\mathrm{CO}_{2}$ gas during stunning increases the anaerobic oxidative metabolism, which further increases the level of blood glucose. It was reported by Nakyinsige et al. (2014) that both stunning methods caused hypercalcemia, hyperglycemia, lactic academia, leucocytosis, and increased activity of enzymes like lactate dehydrogenase, creatine kinase and alanine transaminase. In our study, there was no effect of the stunning method on the blood level of stress biomarkers. Our findings indicated that from the perspective of rabbit welfare, all the analysed stunning methods were similar in regards to stress biomarkers levels. In good quality rabbit meat, the $\mathrm{pH}_{\mathrm{u}}(\mathrm{pH}$ ultimate) measured 24 hours after slaughter, should be in the 5.6 to 5.9 range. In medium quality rabbit meat, the ultimate $\mathrm{pH}$ value is from 6.0 to 6.2 , while a $\mathrm{pH}_{\mathrm{u}}$ above 6.2 is an indicator of low quality rabbit meat (Scharner et al., 1974). According to Dalle Zotte (2002), a pH level measured 24 hours after slaughter that is higher than 5.8, indicates the correct course of glycolysis in the muscle tissue of rabbits. On the basis of the available research results, it can be concluded that the $\mathrm{pH}$ values presented in our study were optimal for rabbit meat, and indicated good quality. As in our study, Nakyinsige et al. (2014) also found no statistical differences in the meat $\mathrm{pH}$ of rabbits slaughtered when using the gas stunning or halal slaughter methods. Dal Bosco et al. (1997) found that the stunning method affected the early process of muscle acidification directly post-mortem. They stated that the highest $\mathrm{pH}$ values were obtained using low voltage current, which did not depend on the strength of the electric current amps. Slight differences were noticed by Maria et al. (2001) concerning the $\mathrm{pH}$ values of meat from animals stunned with the electrical method. In their research, Maria et al. (2001) used different frequencies of electric current. The influence of the stunning method on chicken meat was analysed by Papinaho and Fletcher (1996). The results of their experiment showed that 12 min after slaughter, the $\mathrm{pH}$ was significantly higher in the meat of animals electrically stunned, but the difference disappeared 6 hours post-mortem. They concluded that stunning effects are instantaneous, and fade after slaughter. Lafuente and López (2014) reported that the $\mathrm{pH}$ value of rabbit meat (LTL and BF) measured 45 min post-mortem, was lower in the group of electrically stunned animals compared to those mechanically stunned $(\mathrm{P}<0.01)$. In contrast, no effect of the stunning method on the $\mathrm{pH}$ values of rabbit meat was found in our study. Because the $\mathrm{pH}$ is considered as the major indicator of meat quality, our observations allow us to conclude that all the analysed stunning methods can be used when the goal is to obtain good quality rabbit meat. This optimal stress reaction was similar for all the examined stunning methods.

Meat colour is the major characteristic affecting the consumer's decision to purchase the animal product (Ristić et al., 2017). Meat colour is affected by the muscle biochemistry, including the post-mortem decrease of $\mathrm{pH}$, oxygen consumption, and metmyoglobin reduction (Mancini and Hunt, 2005; Park et al., 2005). The bright colour of rabbit meat is a natural phenomenon, resulting from the reduced amount of myoglobin $(20 \mathrm{mg} / 100 \mathrm{~g})$ in the muscle tissue (Arneth, 1998). In their findings, Nakyinsige et al. (2014) noted significantly greater lightness of rabbit meat in the group of rabbits stunned with gas ( $\mathrm{L}^{*}$ value: 47.5 ) compared to those slaughtered using the halal method ( $\mathrm{L}^{*}$ value: 45.6 ). According to the results presented by Nakyinsige et 
al. (2014), among the analysed colour parameters, only a* and $\mathrm{b}^{*}$ of the rabbit meat colour parameters were not influenced by the stunning method. On the other hand, Dal Bosco et al. (1997) and Lafuente and López (2004) reported that the effect of the stunning method on colour chemical parameters was not significant $(\mathrm{P}>0.05)$. Although there are discrepancies between the results of different studies, the effect of the stunning method on the brightness and yellowness of rabbit meat found in our study is an important observation. It suggests that the used stunning methods can have an effect on the marketing of rabbit meat. This is because the appearance of the meat is a deciding factor for the consumer.

Meat of high technological quality is characterised by low moisture loss during storage (Kołożyn-Krajewska and Sikora, 2010). The marketing of rabbit meat is mainly based on the sale of the whole carcass (vacuum packed or packed without vacuum; in one piece or in portions) on standard supermarket meat trays. It is important to note that the appearance of the carcass significantly affects the consumers' willingness to purchase rabbit meat. This makes it difficult to determine the true effect of the stunning technique on the mentioned traits. Apata et al. (2012) reported lower values of cooking loss, thermal shortening, and drip loss in the meat of rabbits stunned with gas compared to animals electrically stunned $(\mathrm{P}<0.05)$. The research results of Nakyinsige et al. (2014) show that the cooking loss was significantly lower for meat of rabbits subjected to the halal slaughter compared to gas stunned animals (23.27\% vs. $25.70 \%$ after 24 hours and $20.43 \%$ vs. $24.51 \%$ after 7 days). To conclude, the rabbit meat production chain is very complex, with numerous factors affecting the water fractions and water holding capacity of muscle tissue (Dal Bosco et al., 1997; Eikelenboom, 1983). The results of the presented study clearly indicate an effect of the stunning method on the capacity to hold water and hold the content of water fractions. The greater drip loss and free water percentage observed in the meat of electrically stunned animals compared to those mechanically stunned, may negatively affect the purchase decisions of rabbit meat consumers because the effects will become visible during storage of the packed carcasses.

The instrumental measurement of meat tenderness is most frequently done by means of the Warner Bratzler (WB) method, which allows for the analyses of both raw and thermally processed meat (Honikel, 1998). The Volodkevich Bite Jaws are used to analyse tenderness of thermally processed meat (cooked or roasted), to imitate the process of biting. In their study, Kozioł et al. (2012) reported that thermal treatment did not affect the shear force needed to cut through the samples of rabbit meat. Dal Bosco et al. (2001) showed the influence of thermal treatment and the addition of vitamin $\mathrm{E}$ on the quality of commercial rabbit meat. In their experimental group which did not receive vitamin $\mathrm{E}$ in the feed, the value of the shear force of cooked meat was significantly lower than the shear force of the roasted meat $(3.61$ vs. $4.65 \mathrm{~kg} / \mathrm{cm}^{2}$ ). The research conducted by other authors presents much higher values of shear force compared to our study. The value of the cutting force for rabbit meat was found to be $36 \mathrm{~N} / \mathrm{cm}^{2}$ by Pascual and Pla (2008). In their study, Gil et al. (2006) found that the shear force value of rabbit meat ranged from $34.13 \mathrm{~N} / \mathrm{cm}^{2}$ to $37.61 \mathrm{~N} / \mathrm{cm}^{2}$. The differences in the measures of Warner Bratzler Shear Energy in the three stunning groups of our study, may indicate that the consumer will notice 
differences in the texture of thermally processed meat. The electrically stunned rabbits' LTL muscles were characterised by the lowest WB-E values, meaning that less energy was needed to share throughout the sample compared to the mechanically stunned groups.

According to Apata et al. (2012), the stunning method may affect the percentage of some chemical components of rabbit meat, but no such results were obtained in our research. As expected, the major factor determining the chemical composition of rabbit meat analysed in the present research was the muscle type. Muscles types differ with their microstructure, and that influences the chemical composition (Stanley and Swatland, 1976).

\section{Conclusion}

The results of this study showed that all three stunning methods are similar as concerns the welfare of rabbits. This disapproves the stated research hypothesis about the effect of the stunning method on the level of rabbit stress reaction. On the other hand, our results revealed that the stunning method affected some of the physiochemical traits of meat, including: the colour parameters ( $\mathrm{L}^{*}$ and $\mathrm{b}^{*}$ value), drip loss, free water content, plasticity, and the Warner Bratzler Shear Energy of cooked meat. Since the results concerning the stunning methods and rabbit welfare were found to be similar, it is hard to point which of the analysed methods is more beneficial to the overall quality of rabbit meat. The effect of the stunning method on the percentage of different water fractions, water holding capacity, and texture of cooked meat could indicate that changes in the palatability of meat should also be expected. Undoubtedly, there is a need to undertake further research regarding sensory quality and usability of rabbit meat for chilled storage depending on the stunning method used.

\section{References}

A gh w a n Z.A., R e g e n s te in J.M. (2019). Slaughter practices of different faiths in different countries. J. Anim. Sci. Tech., 61: 111-121.

A pat a E.S., Eniolorunda O.O., A ma o K.E., Okubanjo A.O. (2012). Quality evaluation of rabbit meat as affected by different stunning methods. Int. J. Agric. Sci., 2: 054-058.

A r n e th W. (1998). Chemische Grundlagen der Umrötung. Fleischwirtschaft, 8: 868-874.

Becerril-Herrera M., Alonso-Spilsbury M., Lemus-Flores C., Guerrero-Legarreta I., Olmos-Hernández A., Ramírez-Necoechea R., Mota-Rojas D. (2009). $\mathrm{CO}_{2}$ stunning may compromise swine welfare compared with electrical stunning. Meat Sci., 81: $233-237$.

B r o o m D.M. (2010). Animal welfare: an aspect of care, sustainability, and food quality required by the public. J. Vet. Medicine Educ., 37: 83-88.

Commission of the European Union. (2009). Council Regulation (EC) No 1099/2009 of 24 September 2009 on the protection of animals at the time of killing. Official Journal of the European Union, L303, $30 \mathrm{pp}$.

Cullere M., Dalle Zotte A. (2018). Rabbit meat production and consumption: State of knowledge and future perspectives. Meat Sci., 143: 137-146.

Dalle Zotte A. (2002). Perception of rabbit meat quality and major factors influencing the rabbit carcass and meat quality. Livest. Prod. Sci., 75: 11-32. 
Dal Bosco A.D., Castellini C., B ernardini M. (1997). Effect of transportation and stunning method on some characteristics of rabbit carcasses and meat. World Rabbit Sci., 5: 115-119.

Da 1 B o s c o A.D., Cas te 11 in i C., B ernardin i M. (2001). Nutritional quality of rabbit meat as affected by cooking procedure and dietary vitamin E. J. Food Sci., 66: 1047-1051.

D e vi n e C., J e n s e n W.K., D i k e m a n M. (2004). Encyclopedia of Meat Sciences. Academic Press, pp. $405-425$.

E i k e l e n b o o m G. (Ed.) (1983). Stunning of animals for slaughter. MartinusNijhoff. The Hague, 82 pp.

Fazio F., Cas e 11 a S., Giudice E., Giannetto C., Pic cione G. (2015). Evaluation of secondary stress biomarkers during road transport in rabbit. Livest. Sci., 173: 106-110.

Gil M., Ramírez J.A., Pla M., Arino B., Hernandez P., Pascual M., Oliver M.Á. (2006). Effect of selection for growth rate on the ageing of myofibrils, meat texture properties and the muscle proteolytic potential of $m$. longissimus in rabbits. Meat Sci., 72: 121-129.

Gra u R., Ha m m G. (1953). Eineeinfachemetodezurbestimmung di wasserbindung in muskel. Die Naturwissenschafen, 40: 277-279.

H o n i k e l K.O. (1998). Reference methods for the assessment of physical characteristics of meat. Meat Sci., 49: 447-457.

Jos eph P., Schilling M.W., Williams J.B., Radhakrishnan V., Battula V., Chris t e n s e n K., S ch midt T.B. (2013). Broiler stunning methods and their effects on welfare, rigor mortis, and meat quality. World Poultry Sci. J., 69: 99-112.

K ołożyn-Krajews ka D., S i k or a T. (2010). Food safety management: theory and practice (in Polish). Wydawnictwo CH Beck, pp. 67-96.

Kowalska D., Połtowicz K., Bielański P., Niedbała P., Kobylarz P. (2012). Meat quality comparison of rabbits, nutrias and broiler chickens. Rocz. Nauk. Zoot., 2: 237-248.

Kozioł K., Pałka S., Migdał L., Derewicka O., Kmiecik M., Maj D., Bieniek J. (2012). Analysis of the texture of rabbit meat subjected to different means of heat treatment. Rocz. Nauk. PTZ, 12: 25-32.

L a fu e n t e R., Ló pez M. (2014). Effect of electrical and mechanical stunning on bleeding, instrumental properties and sensory meat quality in rabbits. Meat Sci., 98: 247-254.

L o p e z M., C arrilh o M.C., C a m p o M.M., L a fu e n te R. (2008). Halal slaughter and electrical stunning in rabbits: effect on welfare and muscle characteristics. Proc. 9th World Rabbit Congress, Verona, Italy, 10-13.06.2008. World Rabbit Sci. Ass., pp. 1201-1206.

M a n c in i R.A., H unt M. (2005). Current research in meat colour. Meat Sci.,71: 100-121.

Mari a G.A., L o p e z R., L a fue n te M.L. (2001). Evaluation of electrical stunning method using alternative frequencies in commercial rabbits. Meat Sci., 57: 137-143.

Metzger S., Odermatt M., Szendro Z., Mohaupt M., Romvári R., Makai A., H o r n P. (2006). A study of the carcass traits of different rabbit genotypes. World Rabbit Sci., 14: $107-114$.

Nakyinsige K., Sazili A.Q., Zulkifli I., Goh Y.M., Bakar F.A., Sabow A.B. (2014). Influence of gas stunning and halal slaughter (no stunning) on rabbits welfare indicators and meat quality. Meat Sci., 98: 701-708.

Paci G., Cecchi F., Prezius o G., Ci a mpolini R., D'A g a t a M. (2012). Carcass traits and meat quality of two different rabbit genotypes. Ital. J. Anim. Sci., 11: 45.

P a p in aho P.A., F letcher D.L. (1996). The effects of stunning amperage and deboning time on early rigor development and breast meat quality of broilers. Poultry Sci., 75: 672-676.

P a r k B.Y., L e e J.M., H w a n g I.H. (2005). Effect of postmortem metabolic rate on meat color. Asian Austral. J. Anim. Sci., 20: 598.

P a s c u a 1 M., P l a M. (2008). Changes in collagen, texture and sensory properties of meat when selecting rabbits for growth rate. Meat Sci., 78: 375-380.

P o h j a M.S., N i in iva a r F.P. (1957). Die Bestimmung der Wasserbindung des Fleisches mittels der Konstantdruckmethode. Fleischwirtschaft, 9: 193-195.

Ristić M., Troeger K., Dinovic-Stojanovic J., Knezevic N., Damnjanovic M. (2017). Colour and fat content as intrinsic cues for consumers attitudes towards meat product quality. Earth and Environmental Science. IOP Publishing.

SAS. (2012). User's Guide, v. 6.12, 4th Edition, Cary, NC: SAS Institute Inc. 2, 846. 
Scharner E., Schiefer G., S cherer F. (1974). Determination of selected quality criteria for rabbit meat. Nahrung, 18: 47-51.

Skład a now sk a - B ary za J., S t a n is z M. (2019). Pre-slaughter handling implications on rabbit carcass and meat quality - a review. Ann. Anim. Sci., 4: 875-885.

Składanowska-Baryza J., Ludwiczak A., Pruszyńska-Oszmałek E., Kołodziejski P., B ykowska M., Stanisz M. (2018). The effect of transport on the quality of rabbit meat. Anim. Sci. J., 89: 713-721.

S t a n le y D.W., S w at l and H.J. (1976). The microstructure of muscle tissue - a basis for meat texture measurement. J. Texture Stud., 7: 65-75.

Szendro Z., Matics Z., Gerencser Z., Nagy I., Lengyel M., Horn P., Dalle Zotte A. (2010). Effect of dam and sire genotypes on productive and carcass traits of rabbits. J. Anim. Sci., 88: 533-543.

Tumova E., B izkova Z., S krivanova V., Chodova D., Martine c M., Volek Z. (2014). Comparisons of carcass and meat quality among rabbit breeds of different sizes, and hybrid rabbits. Livest. Sci., 165: 8-14.

Received: 11 VII 2019

Accepted: 28 I 2020 